\title{
EFL Students' Perceptions of Social Issues in Famous Works of Art
}

\section{Percepciones de estudiantes de inglés como lengua extranjera sobre temas sociales en obras de arte*}

\author{
Lizmendy Zuhey Bautista Urrego \\ zuly_103@hotmail.com
}

Ingrid Judith Parra Toro

ingridjparrat@gmail.com

Universidad Distrital Francisco José de Caldas, Bogotá, Colombia

This article reports on a qualitative, descriptive, and interpretative research intervention case study of English as a foreign language students' construction of perceptions on social issues found in famous works of art. Participants in this study engaged in the practice of critical thinking as a strategy to appreciate art that expresses social issues. The research was conducted at a Colombian public school over ten days. Famous works of art were presented with the purpose of creating a conversation club in which students were expected to identify and discuss social issues implicit in those works of art. Data were collected through direct observation, field notes, and interviews. Findings showed participants' perceptions of works of art while interacting in English conversations.

Key words: Conversation club, critical thinking, EFL interaction, famous works of art, students' perceptions.

* Received: January 16, 2015. Accepted: February 24, 2016.

How to cite this article (APA 6th ed.):

Bautista Urrego, L. Z., \& Parra Toro, I. J. (2016). EFL students' perceptions of social issues in famous works of art. HOW, 23(1), 85-102. http://dx.doi.org/10.19183/how.23.1.117.

This article is licensed under a Creative Commons Attribution-NonCommercial-NoDerivatives 4.0 International License. License Deed can be consulted at http://creativecommons.org/licenses/by-nc-nd/4.0/. 
Este artículo reporta una investigación cualitativa, descriptiva e interpretativa de inglés como lengua extranjera sobre la construcción de percepciones de los estudiantes acerca de problemas sociales que se encuentran en obras de arte. Los participantes se comprometieron a la práctica del pensamiento crítico como estrategia para apreciar el arte que expresa temas sociales. La investigación se desarrolló en una escuela pública de Colombia durante diez días. Obras de arte famosas fueron presentadas con el propósito de crear un club de conversación en el que los estudiantes identificaron y discutieron temas sociales implícitos en esas obras. Los datos fueron recogidos a través de la observación directa, las notas de campo y entrevistas. Los resultados mostraron las percepciones de los estudiantes sobre las obras de arte mientras interactuaban en inglés.

Palabras clave: club conversacional, interacción en inglés como lengua extranjera, pensamiento crítico, percepciones de los estudiantes, pinturas famosas.

\section{Introduction}

Human beings want to understand the reasons and purposes for every aspect of life. That is why we ask questions and seek answers. This is when our critical thinking skills arise.

This research focuses on how famous works of art can have an impact on students' perceptions of reality through a strategy of critical thinking in a conversation club in the foreign language. This project was developed with tenth graders at a public school in Bogota, Colombia.

During the pedagogical intervention, we encouraged students to discuss social issues represented in works of art. Participants should be able to give opinions in and outside classrooms, critically and creatively, because the knowledge to forge the social construction of reality is born in different kinds of interactions.

Our research is interdisciplinary because we took into consideration four areas to enrich the nature of the study. First, we considered psychology, which provided us with theoretical elements to achieve the completion of the project. Second, art criticism to analyze students' construction of perceptions on social issues found in famous works of art. Another area was sociology, as social issues were covered during the pedagogical implementation. Finally, owing to the linguistic characteristics of this research, we used metrolingualism as we developed our English as a foreign language (EFL) intervention. Our theoretical groundwork is framed on the following authors: Bloom, Facione, and Dewey.

\section{Theoretical Framework}

The study was guided by critical thinking to reflect on famous paintings which transmit social issues. Therefore we worked with three main authors: Bloom (1971), to understand the way students internalize information or a determined group of values and how knowledge 
works while thinking critically; Dewey (1934/2008), to analyze how criticism works in arts appreciation; and Facione (2011), to recognize different forms of judgments followed by skills to think critically.

To analyze how students create their perceptions of arts, we followed Blooms' Taxonomy (1971) (the hierarchical organization of critical thinking stages, see Figure 1) to see how the knowledge undergoes a transformation while students experience different stages seeking critical constructs for criticizing arts. Bloom (1971) states that valuing information implies consistency and stability. The author further affirmed that students are expected to store in their minds certain information and the behavior expected later is the remembering of this information. Here is when knowledge, the first category in Bloom's taxonomy, emerges in different situations and the student realizes that the information relates to social reality. The purpose of this endeavor is to see how students develop a behavior code that regulates their private and civic lives based on ethical principles coinciding with democratic ideals (Bloom, 1971).

To complement knowledge and behavior, Bloom (1971) asserted that it is important that the learner become aware of the terms and symbols, which in the case of our study are the terms: paintings, materials, people, events, and symbols. Students should also learn the definitions or meanings implicit in the art work, and the representation and importance of painting in society. We also want to highlight what Bloom (1971) states as the characterization of values or valuing. He establishes that every piece of information has a specific value, and students go through a hierarchic process to internalize such information. As Pineda (2004) points out, "becoming a critical thinker is a life-long task that is only developed and sharpened through time and learning experiences" (p. 51). That is why we

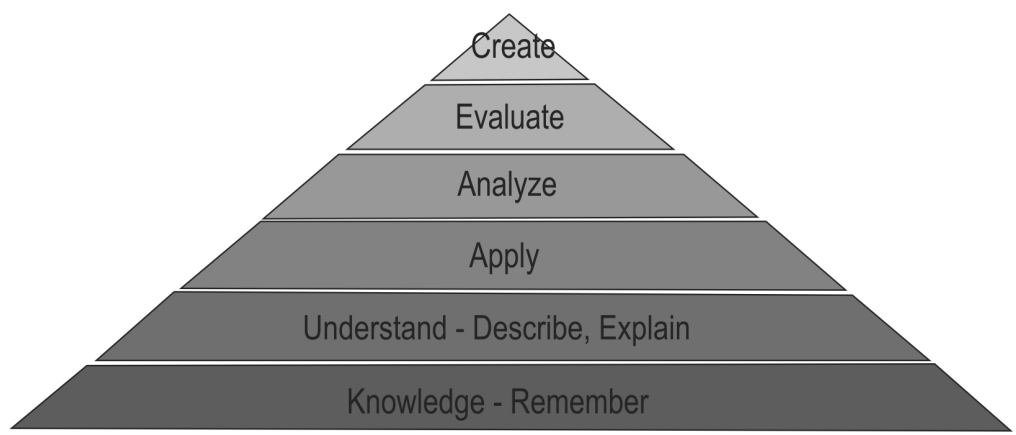

Figure 1. Bloom's Taxonomy of Critical Thinking Stages (Adapted From Anderson \& Krathwohl, 2001) 
believed that this hierarchy is not necessarily a mandatory or strict process; in other words, the stages of critical thinking vary with individuals and personal experiences.

The behavior codes are exposed while students criticize social reality, but here emerges the question: What is it to be a critic? Dewey (1934/2008) states that etymologically and ideologically criticism is making judgments. We consider these judgments opinions that students use to create a vision of reality supported by fundamental ideas.

Moreover, creativity and individual points of view are key aspects in arts' criticism. Art is such a wide field where paintings have different styles and vary from meaning and intention. Art criticism goes beyond the superficial idea of enjoying colors and shapes on a canvas. They are the result of an endeavor to find out that a work of art is an experience. To explain the importance of judgments in arts appreciation, Dewey (1934/2008) states, the absence of an external determined, uniform, and public object does not mean that objective criticism of art is impossible. It means criticism is judgment and all judgment involves an adventure, a hypothetical element that applies to the qualities of an object. Someone who is a critic shall prove him or herself as adventurous and imaginative.

The analysis of arguments deserves special mention as Facione (2011) states that one should establish reasons to support or contest a claim, an opinion, or a point of view (what he calls purposeful reflective judgment, see Figure 2). This, in relation to arts, can be illustrated as trying to find the intentions artists had at the moment of painting. Participants take aspects such as background information, inspiration issues, contextual situation, and experiences to develop a representation that characterizes the inferential flow of reasoning. A critical thinker should be aware that thinking critically is a powerful tool in the search for knowledge.

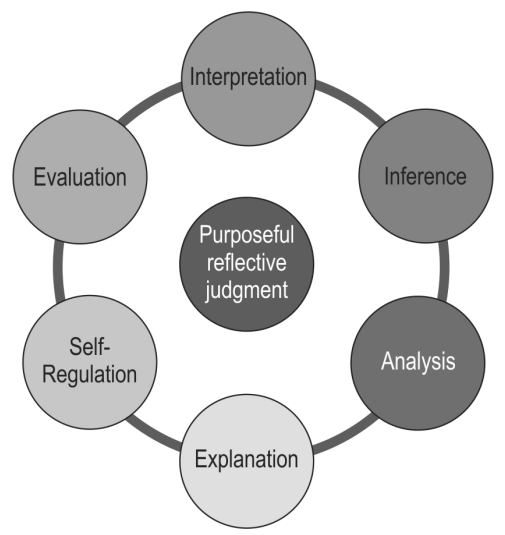

Figure 2. Skills Involved in Purposeful Reflective Judgment (Facione, 2011) 
The artistic perceptions of the participants were considered by us as the most important construct of study, because from the voices of the students is where we can understand and witness the critical thinking skills or processes of thoughts. The foreign language was the instrument used to communicate knowledge during the spaces we created throughout the days we had available to share with the participants and the works of art were the instrument to generate arguments and thoughts.

\section{Research Design}

This study is qualitative and can be explained by Hammersley (2005) as: "discipline-based qualitative research focused on accumulating fundamental knowledge about social processes and institutions" (p. 142). These social processes were performed by participants along the sessions. Furthermore, Lather (2006) states that inquiry opens the space for the pursuit of "inexact knowledges." We agree with this statement because of the flexibility of the characteristics of a qualitative study. This study is descriptive inasmuch as we take into consideration the varieties of the phenomenon and its characteristics. Additionally, it is interpretative because we aimed to understand why the phenomenon occurs and about its impact through time as Timulak (2003) states.

This is how we work on our study due to our intention of understanding the way participants construct their visions of social issues contained in famous works of art during English lessons. The paradigm of this research is socio-critic because of the perspective of social transformation. It considers that knowledge is always built by interests that are based on the needs of the groups. It seeks rational and liberating autonomy of human beings and is achieved by training subjects for participation and social transformation (Alvarado \& García, 2008). We consider that transformation of social reality starts with a process of conscious reflection about real-life problems; this paradigm matches our research due to our interest in students' participation and awareness of issues of their environment.

This research corresponds to a critical approach, which is the focus we consider proper to understanding language as a practice related to art. We should merge a critical approach to literacy, remarking upon the idea that knowledge is something to be understood and analyzed within the forms of experience that students bring to school, as Giroux (1987) states, and a critical approach to the arts where we recognize the statements of Dewey (1934/2008). The first focuses on discourse and text analysis and the second focuses on the analysis of events in the practice of art appreciation.

The type of study that we carried out was the intervention case study; additionally, the method of this research corresponds to critical theory because it emerges as a vehicle to promote an understanding of historical and cultural aspects of society and to generate actions around its transformation (Gamboa, 2011). This is related to the artistic appreciation of 
famous works of art. Furthermore, critical theory can help us unveil ways of changing and improving the learning process.

The participants of this research were ten students of a public school in Bogota, Colombia, who were able to understand formed concepts of different topics in real life as well as construct ideas and knowledge about it. They had an intermediate level of English and recognized the language as a way of building social interactions.

For this study we used different instruments for data collection, including: direct observation (information consigned in the journal), participants' written reflections, and interviews. Participants' written reflections gave us the material to study the process of each student, the knowledge acquired during the sessions, and the positions they considered important while analyzing a work of art, its information, and art history.

The individual interview (see Appendix 1) was the starting point to understand students' personal opinions about the use of critical thinking during English classes. When we presented a topic and showed a work of art we asked for points of view before and after. The evidence in this case was taken from conversations and participation of students. The interview with focal groups was used because we were interested in contacting and confronting different opinions through an open investigation. All these instruments provided us with enough material to triangulate the information and reach conclusions to answer our research question. All of this was supported by Leedy and Ormrod (2001).

To analyze the data gathered from the participants, we used the grounded theory method (Strauss \& Corbin, 1990), open coding, axial coding, and selective coding which guided us to comprehend the events during the sessions. The information gathered allowed us to make a comparison among concepts, see differences and singularities, discriminating concepts in the matrix, as well as getting the category and subcategory that created the body of our data analysis. We aimed to understand how students perceived the messages that are implicit in works of art regarding social issues. This explains the form in which the phenomenon acts upon each student during the sessions and the way in which the art forms participants' opinions.

\section{Pedagogical Intervention}

Our project focused on understanding the critical thinking process of tenth graders at a public school in Bogota when debating on social issues presented in famous works of art as well as the artistic work created by the students themselves. Students analyzed the historical backgrounds of the artists, artistic style and techniques, and the artists' purposes at the time of painting, and the interpretation of arts experts. The students were responsible for expressing their perceptions about the social issues embedded in the artwork presented. 
The conversation club is a space where students can practice speaking in order to improve their language skills such as speaking and listening, gain fluency, have direct contact with the culture, and share experiences with another person in the target language, in this case English; however, this study focuses on the ideas the students had to share. This strategy was implemented so the teacher-researchers could present famous works of art in posters for discussion. We gave a synopsis of the work of art and then asked for students' impressions. Participants in this study engaged in the practice of critical thinking as a strategy to appreciate art that expressed social issues.

First, students proposed their ideas in an environment where they could be free to say anything they felt or thought. Secondly, students analyzed the works of art as well as criticized them, so they could contribute to the conversation club and discern meaningful information and create their perspectives. Finally, students argued their points of view and supported them in real contexts with the purpose of constructing useful interactions and worthwhile practices. The interactions were in Spanish most of the time and there was a switch code from both teachers and students due to the proficiency in the foreign language. This interaction in the mother tongue did not represent a difficulty for our study because we aimed to understand perceptions and thoughts not to seek a meaningful improvement in the foreign language performance. ${ }^{1}$

We were guided by the critical approach throughout this study. Arts appreciation is a product of communicative interactions and of understanding what information students want to transmit. The critical approach, in our case, consists of appreciating a work of art not only for the image itself but also for what it represents.

\section{Data Analysis}

We focused our attention on patterns and commonalities found among students' written reflections and journals that enabled us to confront participants' ideas, opinions, and perspectives. We reviewed the data to categorize the information, considering the phenomenon, problem, and research question of this study (see Appendix 2) from which the category and subcategory emerged. The category is called Social Perceptions Framed in a Humanistic View of Arts because we saw the opinions students had about the artistic product critiqued during sessions about social issues. The sub-category is called Influence of Arts Involving Social Issues because we discovered that the participants expressed their thoughts

1 In our perspective the English classes should improve the skills of the students; however, there should be a space to explore possibilities and learn about culture, for languages are the window to understanding society. The Arts is only a motivational tool to approach the broad world that can be studied by inviting people to see different perspectives through languages. 
about the social manifestations they found in the artwork, understanding that the works of art are communicative and expressive objects that caused impressions (Jensen, 2001).

\section{Social Perceptions Framed in a Humanistic View of Arts}

While answering the interview during the first session we witnessed the way participants felt in an initial stage towards arts, criticism, and English; periodically we observed changes in these three aspects.

An example of a perception from participants was self-recognition, as Facione (2011) established; the individuals have an inner process to see themselves as part of society while they monitor their thoughts. We saw this as participants recognized themselves as actors in similar situations as those presented in the works of art. Violence was the constant social issue we saw. Participants shared their thoughts regarding this issue using pre-established knowledge and associated it with the works of art.

The participants of our study placed special emphasis on child abuse and children as victims of conflicts. In Excerpt 1, the participant expressed the children's desire for happiness; however, he talks about child abuse as a barrier. Calling it a harmful obstacle to happiness, he portrays how difficult is for a child to overcome a situation in which he or she is a victim of abuse and, consequently, loses his or her innocence (Cole, 2011).

\section{Excerpt 1}

In the "painting" that I made I tried to represent a child on the road to "happiness" but it is blocked by child abuse that I wanted to represent as a lot of pikes surrounding a bow, that's why she is crying. I wanted to represent it in the simplest way to make it look made by a child. ${ }^{2}$ (Student's written reflections)

For instance, in Excerpt 2 the participant considers that adults are unconscious of the damage they cause to children because of certain decisions they make. She reflects on the future of a country where children are abused or orphaned because they lose parents (for example, in the Colombian armed conflict). Additionally she concludes that the appropriate management for this matter is to educate children.

\section{Excerpt 2}

Grown-ups often think about them and blah blah blah, but from all the stupidities they do they don't notice that the children are the ones that suffer the consequences.

Besides, if their parents die and they lose it all, what will be of them?

2 Excerpts have been translated from Spanish for publication purposes. 
It supposes that they are like the future and what it has to be done is educate them and not traumatize them. (Student's written reflections)

In Excerpt 3 the participant expressed emotions through colors. He portrayed homosexuality as a rainbow and discrimination as a situation that someone with a different sexual orientation must live with. The participants recognize the repercussions of mauling someone else because of intolerance of differences (Avivi, 2006).

\section{Excerpt 3}

The best session, I believe because it allowed me for a moment to show the role that a discriminated person plays but that before him are the rainbow's colors better represented as the bipolarity. (Student's written reflections)

Additionally, the participants expressed their thoughts regarding discrimination as it is illustrated in Excerpt 4, which came from the journal where we evidenced features from the participants' opinions towards specific artistic creations.

\section{Excerpt 4}

The students discussed discrimination as an important problem of society. They mentioned different types of discrimination such as discrimination by race, sexual orientation, and physical appearance. They gave concrete examples. For instance one student seemed particularly offended by people who made fun of overweight or gay people. (Journal)

During the data analysis we were able to see participants' personal features, such as political positions or religious beliefs. The words bad and good entitled the mode in which students represented their insights. The data showed that in reality students think, for example, that if they do their homework they are good people, but if they do not share their parents' positions or opinions they are bad people.

In Excerpt 5, the participant tried to ascertain the intention of her partners when she sculpted something regarding the topic of life and death. We see the religious conception the participants had about this topic. In her interpretation we see the perception she has towards death and human behavior; she mentions heaven and hell as the two possible paths people follow after they pass away. This is a conception she has from her religious education because she belongs to a Christian community and expressed her idea supporting herself on the Bible and the speeches at the church she attends. It is the duality between good and bad behavior.

\section{Excerpt 5}

Personally I think, Participant $\mathrm{N}$ tried to represent the line of life when it reaches the end, then there are two ways to heaven with white lines, and the hell with brown lines that represents the earth. Cross to the heaven and inverted cross to the hell (red). (Student's written reflections) 
In this topic we noticed that not all participants belonged to a religious community and did not share the same faith. An example of this is how in Excerpt 6 the participant shows her opposition towards religion. She sees the cross as something negative in contrast to the perceptions of other people who believe that it is a symbol that draws people near to God.

\section{Excerpt 6}

The Cross means the religion, it is in the forbidden sign because I think that it is bad but for the rest of people it is not, it is good because it makes us closer to God. (Student's written reflections)

Additionally, as we found in our notes from the journal (Excerpt 7), participants had various opinions about religion. This was expressed in their interpretation of arts related to Christian icons and symbolism (Layton, 2003). Participants also manifested hate or love towards their religious beliefs, all portrayed in their own creations about life and death, inasmuch as they relate those two topics with spirituality. The participants discussed aspects of Colombian society such as traditions and behaviors.

\section{Excerpt 7}

The students feel differently about religion, namely, some of them claim to belong to a particular church, while others say they dislike churches. They expressed that they believe in God while others said they did not believe in that religious figure. (Journal)

For instance, in Excerpt 8 the participant perceived the relationship that a difficult life had on a painting. She recognized that through art someone might capture pain and sadness; when she said that the paintings were cold she referred to the sensation the colors and images transmitted. The artist's sorrow left an impression on her both visually and emotionally. In addition, the artist's experiences served as a reflection of a general view of human behavior; she took the position of the artist and thought about how she could live in a similar situation, thinking about what would be appropriate or good, and considering the commonly held conception about that specific issue.

\section{Excerpt 8}

About Frida Kahlo's live and her husband Diego Rivera, that she had a sad and traumatic live. That in art she could express her pain, that although her husband cheated on her, she was important to him, and if you pay back in kind you will not win anything, and that she was such a good person because she forgave him. Her artistic works were cold, etc. (Student's written reflections)

Another issue that was discussed was the economy. During the first session we analyzed a painting about the drug trafficker Pablo Escobar which allowed us to think about the repercussions illegal commerce might bring to a nation, either positive or negative. 
The participants stated their points of view towards this character as shown in Excerpt 9. We evidenced that participants were influenced by the information they received from the media or other sources such as teachers and friends. Pablo Escobar was a character that was the center of news and an important figure of Colombian history. That is why we noticed that the participants' opinions vary from positive to negative without reaching a consensus about how to feel towards this character.

\section{Excerpt 9}

The students viewed Pablo Escobar as a dual person; they saw a generous man, who helped his countrymen economically, but also a criminal who murdered politicians and people who were against his way. (Journal)

At this point of the analysis we would mention the conception participants had towards criticism. The participants of our study expressed that criticism is giving personal opinions about objects or people's actions that belongs to the second stage (understanding) of Bloom's (1971) Taxonomy. These conceptions of a critic led us to pose the fact that participants were at different stages of critical thinking as a process.

\section{Excerpt 10}

What do you understand as criticism?

S1: To give a self-opinion about what you see.

S2: It is a personal opinion about something you like or dislike, as well as to make some observations. (Interview)

In Excerpt 10 students stated that being critical is giving a personal opinion about something. Another moment of the interview that gave us a hint of what participants considered criticism was when we asked them in which aspects of their lives they thought they had critical thinking. They replied that they are critical in three moments: about objects or situations, towards the environment in which they live, and about their own and others' behavior. However, the judgments students made of materials and behaviors were superficial in the sense that they were based on negative prejudices and lacked a conscientious analysis, which was opposite to the idea of a purposeful reflective judgment proposed by Facione (2011). Students interpret and comprehend that there are a variety of experiences and situations in which they are able to characterize information.

However, as we advanced in our research, we found that students began to become more in tune with Facione's (2011) skills. The misconception that students had about criticism relating emotional negative prejudices towards other people changed. They began to give meaning to situations, interpreting ideas and sharing thoughts, among others. They engaged in processes involving the self. 
Influence of arts involving social issues. Through the analysis of works of art we were able to hear participants' thoughts of the world through emotions, colors, images, and perceptions of human crafts.

\section{Excerpt 11}

With arts I learned more and became less ignorant about this subject, I realize that in art is more reflected the violence about the world, and the artists show with their artistic works what they think, or see and sometimes they cannot speak up because of the society or the government itself. (Student's written reflections)

Most of the time people make deductions about what they constantly see; art is one of the media of expression about which participants make reflections, and as the participant in Excerpt 11 states, "with arts I learned more and became less ignorant about this subject." The participant considered arts an unknown area but once he understood and gained knowledge about it, he considered that art reflects other matters and experiences about the world. The participant recognizes the influence of arts on him, stating that he has seen a clear change since the first session: "I . . became less ignorant about this subject." The participant is conscientious about the codes and behaviors when we live in society.

\section{Excerpt 12}

We learned about Picasso that he had many names and that was born in Spain that he left Spain because there was so much violence and his artistic work was focused on it, that everything is connected and everyone is affected. (Student's written reflections)

In Excerpt 12, the participant assumed arts is a way to express how the artist lived; it is important to note how the participant recognized a reality in Spain and immediately related it to his own. As the participant said, "his work is focused on violence that everything is connected and everyone is affected by it." Art is influencing the participant while he recognizes the connection between Spanish and Colombian realities and admits the consequences are the same.

Presenting a painting that portrayed war in Spain created awareness in participants about the war in their own country. They started perceiving violence not as a one-nation issue but as a common factor that affects everyone. Just by watching the news, reading newspapers or websites, and listening to close experiences from friends or family, they are informed about Colombian armed conflicts; this is what participants developed in terms of thoughts about art.

The participants characterize the quality of art to set and perpetuate memories, as is the case in how violent events in the past still affect innocent people in the present. This is evident in Excerpt 13. 


\section{Excerpt 13}

Today's session was interesting because we could embody the violence as I see it and it was interesting to know the way in which people see differently the idea of violence that is marked in many innocents' lives. (Student's written reflections)

Participants stated that human beings are unique and that their development in different areas is equally unique. They felt that showing emotions through art is possible for anyone, as shown in Excerpt 13. This is important because, as Dewey (1934/2008) states, pictures are present material passed through the alembic of personal experience. They have no precedents in existence or in universal being. But, nonetheless their material came from the public world and so has qualities in common with the material of other experiences (Dewey, 1934).

\section{Excerpt 14}

It is a good experience because, I didn't feel interest in arts before, but I have noticed that art is a world's critic and it makes us see how some things in the world really are. (Student's written reflections)

\section{Excerpt 15}

I liked this session so much because the topic about Frida Kahlo is interesting. It is very interesting to know everything that she lived, she was a great artist, passionate about what she did despite her sufferings. It reflects all the pain of the world. (Student's written reflections)

\section{Excerpt 16}

At the end of the session we evidenced that students were enthusiastic about continuing with the conversational club, they often asked us questions about authors and artistic currents. Some of them claimed that they were going to search more information about the art they remembered and liked. They wondered about meanings and interpretations for the art that was familiar to them. (Journal)

The art from the sessions started making sense in participants' daily life. They began thinking how one particular case in the world can be seen in a wider vision of how things work in the world. In Excerpt 14, the participant said "I have noticed that art is a world's critic and it makes us see how some things in the world really are." The participant expanded his perspective from a single piece of art to a world vision. In Excerpt 15, the participant wrote that "Frida Kahlo ... was a great artist, passionate about what she did despite her sufferings" and concludes, "It reflects all the pain of the world." There is evidence of the relationship the participant found between Frida's life story and what is usual to see in the world, which is pain. The participant also talked about people trying their best to transform pain into passion. Additionally, the participants showed a real interest in continuing to learn about arts and recognized its importance for their closest environment, as can be evidenced in Excerpt 16. 
This section showed the transformation participants' ideas underwent throughout the sessions, and how the reflections students engaged in evidenced the process they carried out in learning about the arts. Participants recognized qualities and senses in works of art like expression, reality, and world conceptions. The art and sessions generated a change in participants' ideas and reflections, making their opinions wider and deeper.

\section{Conclusion}

We will draw the main conclusions we had focused on and the principles that guided this research; firstly, the perception of arts; secondly, the outcome from participants' ideas in the identification of social issues while appreciating famous works of art; and finally, the transformation of participants' reflections in regard to arts.

We noticed that participants realized that behind a work of art (by using critical thinking as a tool to interpret, analyze, and express it), there is a human experience, there is an artist's purpose coding in it. This follows the main category "Social Perceptions Framed in a Humanistic View of Arts" where the different human experiences (participants' experiences and artists' experiences) are shared. Each one of the perceptions they had along the research gave us the material to understand that the participants felt connected to the feelings and to the human experiences transmitted in the art work presented. Furthermore, the participants by themselves identified social issues in famous works of art, which was made of judgments and different points of view going through the knowledge, understanding, application, and analysis stages under Bloom's (1971) Taxonomy.

There was a transformation in participants' perceptions. When we began the sessions, they manifested that art was something superficial and individual, but throughout the sessions, they comprehended that arts are for everyone and that works of art can be read by judging and thinking critically. This conclusion belongs to the subcategory "Influence of Arts Involving Social Issues;" where the points of view and the form of expressing ideas were transformed into more elaborated ideas along the sessions.

Also, the participants demonstrated how they built their perceptions and became aware of the importance of supporting and reproducing those perceptions. They understood that art was more than a drawing and started with the idea that it is possible to understand thoughts, events, individualities, and even the behavior of a community just by looking carefully at what an artist captured on canvas. This is an influence of arts, which provides them with a human experience, transporting them to a world vision about the social issues that works of art show.

We placed special emphasis on what arts represented for them before and after the pedagogical intervention. As Dewey (1934/2008) mentioned, in common conception, a work 
of art is often identified with the building, book, painting, or statue in its existence apart from human experience. But thinking about art only as physical objects is to dehumanize a tool that provides students with diverse ways to understand the nature of human beings in a profound experience of analysis and criticism. Participants recognized critical thinking as a powerful instrument to find knowledge in the work of art, not just something on a canvas but as a human experience inside each one.

\section{References}

Alvarado, L., \& García, M. (2008). Características más relevantes del paradigma socio-crítico: su aplicación en investigaciones de educación ambiental y de enseñanza de las ciencias realizadas en el doctorado de educación del instituto pedagógico de Caracas. [Most relevant characteristics of the socio-critical paradigm: Its application in environmental education and science teaching research]. Sapiens: Revista Universitaria de Investigación, 9(2), 187-202.

Anderson, L. W., \& Krathwohl, D. R. (Eds.). (2001). A taxonomy for learning, teaching, and assessing: A revision of Bloom's taxonomy of educational objectives. New York, NY: Longman.

Avivi, Y. (2006). Room for variation? The experience of Colombian gay asylum seekers and asylees in Miami. Sociedad y Economia, 11. Retrieved from http:/ / sociedadyeconomia.univalle.edu.co/ index.php/sye/article/view/158.

Bloom, B. S. (1971). Taxonomía de los objetivos de la educación: la clasificación de las metas educacionales [Taxonomy of educational objectives: The classification of educational goals.] Buenos Aires, AR: El Ateneo.

Cole, R. T. (2011, November 15). Letters: Child abuse victims lose more than innocence [comment]. USA Today. Retrieved from http://usatoday30.usatoday.com/news/opinion/ letters/story/2011-11-15/Penn-State-scandal-child-sex-abuse/51225638/1

Dewey, J. (1934/2008). El arte como experiencia (J. Claramonte, Trans.) [Art as experience]. Barcelona, ES: Paidós.

Facione, P. A. (2011). Critical thinking: What it is and why it counts. Millbrae, CA: The California Academic Press.

Gamboa, R. (2011). El papel de la teoría crítica en la investigación educativa y cualitativa [The role of critical theory in educational qualitative research]. Revista Electrónica Diálogos Educativos, 11(21), 48-64.

Giroux, H. A. (1987). Critical literacy and student experience: Donald Graves' approach to literacy. Language Arts, 64(2), 175-181.

Hammersley, M. (2005). Close encounters of a political kind: The threat from the evidence-based policy-making and practice movement. Qualitative Researcher, 1, 2-4.

Jensen, J. (2001). Art, the public and Deweyan cultural criticism. In D. K. Perry (Ed.), American pragmatism and communication research (pp. 109-126). Mahwah, NJ: Taylor \& Francis e-Library. 
Lather, P. (2006). Foucauldian scientificity: Rethinking the nexus of qualitative research and educational policy analysis. International Journal of Qualitative Studies in Education, 19(6), 783-791. http://dx.doi.org/10.1080/09518390600976006.

Layton, R. (2003). Art and agency: A reassessment. The Journal of the Royal Anthropological Institute, 9(3), 447-464 http://dx.doi.org/10.1111/1467-9655.00158.

Leedy, P. D., \& Ormrod, J. E. (2001). Practical research: Planning and design (7th ed.). Upper Saddle River, NJ: Merrill Prentice Hall.

Pineda, C. (2004). Critical thinking in the EFL classroom: The search for a pedagogical alternative to improve English learning. Íkala, Revista de Lenguaje y Cultura, 9(15), 45-80.

Strauss, A., \& Corbin, J. (1990). Basics of qualitative research: Grounded theory, procedures and techniques. London, UK: Sage.

Timulak, L. (2003). Empowerment events in process-experiential psychotherapy of depression: An exploratory qualitative analysis. Psychotherapy Research, 13(4), 443-460.

\section{The Authors}

Lizmendy Zuhey Bautista Urrego holds a BA in Modern Languages from Universidad Distrital, Colombia. She has taught in private schools in Bogota. She was a speaker at the III Encuentro Bi-universitario de Futuros Maestros de Lenguas Extranjeras sobre Investigación Formativa e Innovación Pedagógica, Universidad Industrial de Santander (Colombia). She studied English proficiency at Boston Academy of English, MA.

Ingrid Judith Parra Toro holds a BA in Modern Languages from Universidad Distrital, Colombia. She has taught in private schools in Bogota. She was a speaker at the III Encuentro Bi-universitario de Futuros Maestros de Lenguas Extranjeras sobre Investigación Formativa e Innovación Pedagógica, Universidad Industrial de Santander (Colombia). She completed a course in ESL from I.E.L.I. Hunter College, NY. 


\section{Appendix 1: Questionnaire Used to Find out Students' First Opinions Regarding Critics and Arts}

\section{Pedagogical experience and research in secondary school}

Name: Grade: Date:

1. Do you have any interest in visual arts (paintings, sculptures, murals, etc.)? If your answer is yes, please give some examples.

2. Do you think that visual arts contribute to your environment? Explain.

3. What do you understand criticism to be?

4. Do you consider yourself a critic with the topics you learn in English classes? Explain.

5. If you have it, in which aspects of your life do you consider you have critical thinking? 


\section{Appendix 2: Matrix Used in Data Analysis}

\begin{tabular}{|c|c|}
\hline Activity 1 & $\begin{array}{l}\text { Filling the questionnaire used to find out students' first opinions } \\
\text { regarding critics and arts. }\end{array}$ \\
\hline Objective & $\begin{array}{l}\text { Establish a diagnosis about how students perceive critics and arts at } \\
\text { first sight. }\end{array}$ \\
\hline Description & $\begin{array}{l}\text { Teachers explain each question presented in the interview } \\
\text { (questionary), asking students to write their opinions in Spanish. }\end{array}$ \\
\hline Resources & $\begin{array}{l}\text { Appendix 1: Questionnaire Used to Find out Students' First } \\
\text { Opinions Regarding Critics and Arts. }\end{array}$ \\
\hline Data collection method & Interviews \\
\hline Activity 2 & Explanation and execution of participants' written reflections. \\
\hline Objective & $\begin{array}{l}\text { Have a personal conclusion from participants at the end of each } \\
\text { session. }\end{array}$ \\
\hline Description & $\begin{array}{l}\text { Teachers explain the purpose of the written reflections, the } \\
\text { importance of being a critic while writing an opinion and at the end } \\
\text { of the session students write their opinions. }\end{array}$ \\
\hline Resources & $\begin{array}{l}\text { Written paper by students about their reflection of the topic } \\
\text { managed in class. }\end{array}$ \\
\hline Data collection method & Participants' written reflections \\
\hline Activity 3 & Journal fulfillment \\
\hline Objective & $\begin{array}{l}\text { Have a teacher's personal opinion and important observations } \\
\text { played out during conversations in class. }\end{array}$ \\
\hline Description & $\begin{array}{l}\text { At the end of each session the teachers write a journal about } \\
\text { observations during class regarding the conversations held in it. }\end{array}$ \\
\hline Resources & Written teachers' perceptions and observations. \\
\hline Data collection method & Direct observation (information consigned in the journal). \\
\hline
\end{tabular}

